\title{
Pengolahan Alat Ungkap Masalah (AUM) dengan Menggunakan Komputer Bagi Konselor
}

\author{
Ifdil Ifdi1 ${ }^{\left.1^{*}\right)}$, Asmidir Ilyas ${ }^{2}$, Elfi Churnia ${ }^{3}$, Lira Erwinda ${ }^{4}$, Nilma Zola ${ }^{5}$, Rima \\ Pratiwi Fadli ${ }^{6}$, Alfina Sari ${ }^{7}$ Refnadi Refnadi ${ }^{8}$ \\ ${ }^{12}$ Universitas Negeri Padang, ${ }^{345678}$ Indonesian Institute for Counseling Education and Therapy \\ *Corresponding author, e-mail: ifdil@konselor.org
}

\begin{abstract}
Along with the development of technology, counselors began to use information media as a tool in carrying out its duties, which then known as e-counseling service. The real form of application of ecounseling is with the emergence of counseling services online. Furthermore, the use of other application programs that support the implementation of the tasks of the counselor, such as the birth of the application program of the Alat Ungkap Masalah (AUM) with the base of the Microsoft Access program, e-Counseling technology in this program allows display more information regarding the problems of respondents, in it is mainly students who later can be used as a tool for counselors in carrying out professional duties. This training activity is a similar training that has also been conducted in other districts in West Sumatra province, and in planning will be done in all districts / cities in West Sumatra, so that knowledge and skill mastery can be improved.
\end{abstract}

Keywords: Processing AUM
Received October 29, 2017; Revised November 22, 2017; Accepted December 25, 2017; Published Online January, 2018

Conflict of Interest Disclosures: The authors declare that they have no significant competing financial, professional or personal interests that might have influenced the performance or presentation of the work described in this manuscript.

How to Cite: Ifdil, I., et.all. (2017). Pengolahan Alat Ungkap Masalah (AUM) dengan Menggunakan Komputer Bagi Konselor. Jurnal Aplikasi IPTEK Indonesia, 1(1), 6-10. DOI: 10.24036/4.113

\section{Pendahuluan}

Teknologi informasi yang hadir dewasa ini memberikan tantangan besar bagi para konselor untuk ikut berperan serta dalam menguasai perkembangan teknologi tersebut (Safitri, J. 2017; Granger, M. J., Dick, G., Jacobson, C. M., \& Van Slyke, C. 2007; Hanna, N. K. 2010). Beriringan dengan kondisi tersebut tidak menutup kemungkinan penyelenggaraan konseling hanya dilakukan secara face to face dalam satu ruang tertutup (Siradjuddin, H. K. 2017), namun bisa dilakukan melalui format jarak jauh (Ardi, Z., Yendi, F. M., \& Ifdil, I., 2013; Taufik, T., \& Ifdil, I., 2013; Dina, D. A. M., Sofiana, A., Wahyuningtyas, N., \& Bhakti, C. P. 2016; Sahi, A., Rai, P., Oh, S., Ramasamy, M., Harbaugh, R. E., \& Varadan, V. K. 2014). Konselor menggunakan media informasi sebagai alat bantu dalam menjalankan tugasnya, yang selanjutnya dikenal dengan istilah pelayanan e-konseling (Ifdil, I., \& Ardi, Z., 2013). Wujud nyata aplikasi dari e-konseling adalah dengan bermunculannya pelayanan konseling secara online, melalui situs-situs penyedia layanan konseling online, atau yang lebih sederhana konseling yang dilakukan melalui telpon, hand phone dan/atau melalui email pribadi dan beberapa program aplikasi untuk chatting seperti skype, yahoo messenger dan sebagainya. Juga pemanfaatan program aplikasi lainnya yang mendukung penyelenggaraan tugas para konselor, seperti lahirnya program aplikasi pengolahan Alat Ungkap Masalah (AUM).

Ada dua jenis alat untuk mengungkapkan masalah-masalah siswa dan mahasiswa secara menyeluruh yang telah dikembangkan, yaitu; (1) alat untuk mengungkapkan masalah-masalah umum dan (2) alat untuk mengungkapkan masalah-masalah khusus yang berkaitan dengan upaya dan penyelenggaraan kegiatan 
belajar. Kedua jenis alat ungkap itu yang dikenal dengan AUM "Umum" dan AUM "Belajar". AUM "Belajar" itu lebih khusus lagi dinamakan AUM PTSDL. Namun hal ini terfokus pada AUM Umum, dalam bentuknya yang menyeluruh AUM meliputi:

\begin{tabular}{lccc}
\hline No & Sasaran Penggunaan & \multicolumn{2}{c}{ Format AUM } \\
& & AUM UMUM & AUM Belajar \\
$\mathbf{1}$ & Perguruan Tinggi & AUM Umum F1 & AUM PTSDL F1 \\
$\mathbf{2}$ & SLTA & AUM Umum F2 & AUM PTSDL F2 \\
$\mathbf{3}$ & SLTP & AUM Umum F3 & AUM PTSDL F3 \\
$\mathbf{4}$ & SD & - & AUM PTSDL F4 \\
$\mathbf{5}$ & Masyarakat & AUM Umum F5 & - \\
\hline
\end{tabular}

Konselor sekolah selama ini melakukan pengungkapan masalah tidak optimal, kondisi masalah seperti gangguan umum psikologis di sekolah seperti stress (Taufik, T., \& Ifdil, I., 2013; Barseli, M., \& Ifdil, I., 2017), depresi, self-efficacy rendah (Ifdil, I., Apriani, R., Yendi, F. M., \& Rangka, I. B., 2016) dan bahkan lainya seperti karakter anak (Zola, N., Ilyas, A., \& Yusri, Y., 2017) tidak dapat diungkapkan dan bahkan secara sederhana pengolahan dan pengadministrasian AUM dan melakukan pengolahan secara manual, sehingga memakan tenaga yang besar dan waktu yang tidak efisien. Untuk membantu para konselor akhirnya Tim Pengembang Instrumen atas izin tim pengusun instrument AUM (Prayitno dkk) berinisiatif untuk mengembangkan sebuah program aplikasi AUM dengan basis program Microsoft Acces, teknologi ekonseling pada program ini memungkinkan menampilkan lebih banyak lagi informasi berkenaan dengan masalah-masalah responden (Heinlen, K. T., Welfel, E. R., Richmond, E. N., \& Rak, C. F., 2003; Kolog, E. A., Sutinen, E., Suhonen, J., Anohah, E., \& Vanhalakka-Ruoho, M., 2015), dalam hal ini terutama siswa (Ifdil, I., \& Taufik, T., 2016). yang nantinya dapat dijadikan alat bantu bagi konselor dalam menjalankan tugas profesionalnya. Kegiatan pelatihan ini merupakan pelatihan serupa yang juga sudah dilakukan di kabupaten/kota lain di propinsi Sumatera Barat, dan dalam perencanaannya akan dilakukan pada semua kabupaten/kota yang ada di Sumatera Barat, sehingga pengetahuan dan penguasaan ketrampilan dapat ditingkatkan .

\section{Metodologi}

Pelaksanaan kegiatan pelatihan ini digunakan metode ceramah (Hussain, A., Azeem, M., \& Shakoor, A. 2011), tanya jawab (Xue, X., Jeon, J., \& Croft, W. B. 2008, July), diskusi dan praktek penggunaan program. Metode ceramah digunakan pada awal kegiatan, dimana pemateri menyajikan bahan-bahan yang relevan dengan pelatihan mencakup materi-materi yang perlu diketahui oleh peserta pelatihan. Metode tanya jawab dilakukan setelah peserta mengetahui dan memahami sebagian konsep yang sudah diberikan sebelumnya namun masih belum mantap dan masih terdapat keraguan. Peserta diminta untuk bertanya secara sukarela dan terbuka. Metode diskusi digunakan dalam rangka memberikan kesempatan kepada peserta untuk mengungkapkan pengalaman, pendapat, permasalahan, dan usaha yang selama ini dilakukan terkait dengan materi pelatihan sehingga semua permasalahan dan kendala yang dihadapi selama ini dan saat pelatihan dapat terentaskan. Kemudian metode praktik dilakukan untuk memantapkan pemahaman dan penguasaan keterampilan penggunaan program kepada konselor serta melakukan pengenalan langsung kepada konselor yang selama ini belum pernah menggunakan program aplikasi computer pengolahan AUM Umum.

\section{Hasil dan Pembahasan}

Berdasarkan hasil evaluasi kegiatan yang telah dilakukan dapat dikatakan bahwa kegiatan pelatihan ini berhasil. Hal ini didasarkan pada antusias peserta yang mengikuti kegiatan mulai dari awal hingga akhir kegiatan, tingkat keseriusan peserta dalam menerima materi, partisipasi peserta dalam proses tanya jawab, diskusi dan semangat peserta mengikuti program praktik pengolahan AUM yang dilakukan. Dan bukan 
Jurnal Aplikasi IPTEK Indonesia

ISSN Print: 2614-2465 - ISSN Online: 2614-2473

hanya itu saja ditambah dengan banyaknya peserta yang meminta biodata pemeteri untuk diskusi lebih lanjut berkanaan dengan materi pelatihan.

Berdasarkan hal tersebut kami dari tim yakin bahwa kegiatan ini merupakan sebuah terobosan yang bagus untuk pengingkatan pengetahuan, pemahaman serta ketrampilan para konselor sekolah di Kabupaten Tanah Datar, sehingga nantinya dapat membantu para konselor dalam menjalankan tugasnya secara optimal.

Kehadiran teknologi informasi yang semakin berkembang dewasa ini memberikan tantangan bagi para konselor untuk ikut berperan serta dan menguasainya (Hatch, K. D., \& McCarthy, C. J. 2003). Penguasaan teknologi dimaksudkan dalam rangka untuk menjalankan tugas secara optimal, baik itu pada setting sekolah dan di luar sekolah. Konselor benar-benar dituntut untuk memiliki WPKNS (wawasan, pengetahuan, ketrampilan, nilai dan Sikap), karena tersebut sangatlah penting guna mmbentuk karakter siswa (Ifdil, I., 2010). Selain itu juga dibutuhkan sarana dan prasana, seperti ketersediaan ruang konseling, buku-buku, media visual seperti rekaman konseling, video layanan dan pemunculan program-program aplikasi iventori dan instrumen serta yang lainnya yang pada intinya untuk membantu para konselor dalam menjalankan tugasnya.

Munculnya terobosan-terobosan baru dalam bidang konseling, seperti munculnya istilah pelayanan ekonseling (Koutsonika, H. 2009; Salleh, A., Hamzah, R., \& Nordin, N. 2011; Camillus, C. M. 2007). Wujud nyata aplikasi dari e-konseling adalah dengan bermunculannya pelayanan konseling secara online, melalui situs-situs penyedia layanan konseling online (Kraus, R., Stricker, G., \& Speyer, C. (Eds.). 2010; Pollock, S. L. 2006; Salleh, A., Hamzah, R., Nordin, N., Ghavifekr, S., \& Joorabchi, T. N. 2015), atau yang lebih sederhana konseling yang dilakukan melalui telpon (Djaalia, N. A., \& Sappaileb, N. 2013), hand phone dan/atau melalui email pribadi (Salleh, A., Hamzah, R., Nordin, N., Ghavifekr, S., \& Joorabchi, T. N. 2015) dan beberapa program aplikasi untuk chatting seperti skype, Yahoo Mesegger dan sebagainya (Ifdil, I. 2013; Petrus, J., \& Sudibyo, H. 2017). Juga pemanfaatan program aplikasi lainnya yang mendukung penyelenggaraan tugas para konselor, seperti lahirnya program aplikasi pengolahan Alat Ungkap Masalah (AUM).

Namun kenyataan selama ini menunjukkan bahwa, sebagian besar konselor sekolah belum mampu menggunakan teknologi informasi, belum bisa memanfaatkannya, termasuk pengolahan AUM yang selama ini dilakukan secar manual. Kondisi ini bisa ditingkatkan dengan kerjasama yang baik antara perguruan tinggi dengan para penyenggara BK di lapangan. Salah satunya melalui kegiatan seperti yang dilakukan ini yaitu, melatih konselor untuk melakukan pengolahan dengan menggunakan Program Aplikasi Komputer Pengolahan AUM.

Setelah mengikuti kegiatan Pelatihan Pengolahan Alat Ungkap Masalah (AUM) dengan Menggunakan Komputer bagi Konselor di Kabupaten Tanah Datar, peserta telah mendapatkan wawasan, pengetahuan, pemahaman dan ketrampilan dalam menunjang penyelenggaraan tugas sebagai konselor di sekolah, selain itu pelatihan ini telah membawa nuansa baru dalam dunia konseling setempat, kegiatan ini memberikan semangat kembali kepada para konselor untuk lebih giat lagi, bahkan harapan ini dikemukakan langusng oleh perwakilan dari peserta agar kegiatan serupa lebih sering untuk dilaksanakan.

\section{Kesimpulan}

Pengolahan Alat Ungkap Masalah (AUM) dengan Menggunakan Komputer Bagi Konselor, dapat menambah wawasan, pengetahuan, pemahaman dan keterampilan dalam pengadministrasian dan pengalikasian Alat Ungkap Masalah (AUM) SLTA. Pengolahan Alat Ungkap Masalah (AUM) membawa nuansa baru dalam dunia konseling setempat, dari pengolahan manual yang dilakukan oleh konselor selama ini telah dapat dibandingkan langsung oleh peserta dengan pengolahan dengan menggunakan program komputer. Pengolahan dengan program lebih evisien dibandingkan dengan proses pengolahan manual. Selerai dengan kesimpulan yang ada, untuk itu saran yang dapat diberikan oleh penulis yaitu bagi pihak UNP perlu melakukan kegiatan pengabdian kepada masyarakat yang terkait dengan Pengolahan Alat Ungkap Masalah (AUM) dengan Menggunakan Komputer Bagi Konselor lebih lanjut karena dapat meningkatkan profesionalitas konselor dalam menjalankan tugasnya. Kemudian diharapkan kesedian pengawas bidang BK untuk ikut serta dalam kegiatan ini perlu dicontoh oleh pengawas-pengawas lain sehingga tidak terjadi miskomunikasi ataupun miskonsepsi antara pengawas dan konselor sekolah. 
Diharapkan kepada para konselor sekolah hendaknya senantiasa meningkatkan wawasan, pengetahuan, ketrampilan, nilai dan Sikap dalam menjalankan tugasnya sebagai abdi negara.

\section{Acknowledgment}

Terimakasih kepada Musyawarah Guru BK, Ketua LP2M Unoiversitas Negeri Padang, TIM Pelaksana, dan semua pihak yang sudah terlibat dalam pelaksanaan kegiatan dan spesial untuk IICET tim.

\section{Referensi}

Ardi, Z., Yendi, F. M., \& Ifdil, I. (2013). Konseling Online: Sebuah Pendekatan Teknologi Dalam Pelayanan Konseling. Jurnal Konseling dan Pendidikan, 1(1), 1-5.

Barseli, M., \& Ifdil, I. (2017). Konsep Stres Akademik Siswa. Jurnal Konseling dan Pendidikan, 5(3), 143148.

Camillus, C. M. (2007). To e-or not to e-: An analogue study of disclosure rates in e-counseling (Doctoral dissertation, The Ohio State University).

Dina, D. A. M., Sofiana, A., Wahyuningtyas, N., \& Bhakti, C. P. (2016, March). Aplikasi Cyco (CYBER COUNSELING): Alternatif Model Konseling di Sekolah. In Prosiding Seminar Nasional" Optimalisasi Peran Pendidikan dalam Membangun Karakter Anak untuk Menyongsong Generasi Emas Indonesia" (pp. 136-140). Prodi BK dan PGSD FKIP UAD.

Djaalia, N. A., \& Sappaileb, N. (2013). A systematic review: Group Counselling for older peoplewith depression. In 2nd International Seminar on Quality and Affordable Education (ISQAE 2013). Jakarta: UI, di akses tanggal (Vol. 22).

Granger, M. J., Dick, G., Jacobson, C. M., \& Van Slyke, C. (2007). Information systems enrollments: Challenges and strategies. Journal of Information systems education, 18(3), 303.

Hanna, N. K. (2010). Transforming government and building the information society: Challenges and opportunities for the developing world. Springer Science \& Business Media.

Hatch, K. D., \& McCarthy, C. J. (2003). Challenge course participation as a component of experiential groups for counselors in training. Journal for Specialists in Group Work, 28(3), 199-214.

Heinlen, K. T., Welfel, E. R., Richmond, E. N., \& Rak, C. F. (2003). The scope of webcounseling: A survey of services and compliance with NBCC standards for the ethical practice of webcounseling. Journal of Counseling \& Development, 81(1), 61-69.

Hussain, A., Azeem, M., \& Shakoor, A. (2011). Physics teaching methods: scientific inquiry vs traditional lecture. International Journal of Humanities and Social Science, 1(19), 269-276.

Ifdil, I. (2010). Pendidikan Karakter dalam Bimbingan dan Konseling. Pedagogi: Jurnal Ilmu Pendidikan, 10(2), 55-61.

Ifdil, I., \& Ardi, Z. (2013). Konseling Online Sebagai Salah Satu Bentuk Pelayanan E-konseling. Jurnal Konseling dan Pendidikan, 1(1), 15-22.

Ifdil, I., Apriani, R., Yendi, F. M., \& Rangka, I. B. (2016). Level of studentsself-efficacy based on gender. COUNS-EDU: The International Journal of Counseling and Education, 1(1), 29-33.

Ifdil, I., \& Taufik, T. (2016). Urgensi Peningkatan dan Pengembangan Resiliensi Siswa di Sumatera Barat. Pedagogi: Jurnal Ilmu Pendidikan, 12(2), 115-121.

Kolog, E. A., Sutinen, E., Suhonen, J., Anohah, E., \& Vanhalakka-Ruoho, M. (2015, September). Towards students' behavioral intention to adopt and use e-counseling: An empirical approach of using Unified Theory of Acceptance and Use of Technology model. In AFRICON, 2015 (pp. 1-6). IEEE.

Koutsonika, H. (2009). E-Counseling: the new modality. Online Career Counseling-a challenging opportunity for greek tertiary education.

Kraus, R., Stricker, G., \& Speyer, C. (Eds.). (2010). Online counseling: A handbook for mental health professionals. Academic Press.

Petrus, J., \& Sudibyo, H. (2017). Kajian Konseptual Layanan Cyberconseling. Konselor, 6(1), 6-12.

Pollock, S. L. (2006). Internet counseling and its feasibility for marriage and family counseling. The Family Journal, 14(1), 65-70.

Safitri, J. (2017). Pemanfaatan teknologi komputer dalam pembelajaran di SMK Yadika 5 Pondok Aren (Bachelor's thesis, Fakultas Ilmu Tarbiyah dan Keguruan). 
Jurnal Aplikasi IPTEK Indonesia

ISSN Print: 2614-2465 - ISSN Online: 2614-2473

Sahi, A., Rai, P., Oh, S., Ramasamy, M., Harbaugh, R. E., \& Varadan, V. K. (2014, April). Neural activity based biofeedback therapy for Autism spectrum disorder through wearable wireless textile EEG monitoring system. In Proc. of SPIE Vol (Vol. 9060, pp. 90600D-1).

Salleh, A., Hamzah, R., \& Nordin, N. (2011). From Face-to-Face to Cyber Mode: Life-Long Learning in Counseling for All. In 7th WSEAS/IASME International Conference on Educational Technologies, EDUTE'11.

Taufik, T., \& Ifdil, I. (2013). Kondisi Stres Akademik Siswa SMA Negeri di Kota Padang. Jurnal Konseling dan Pendidikan, 1(2), 143-150.

Zola, N., Ilyas, A., \& Yusri, Y. (2017). Karakteristik Anak Bungsu. Jurnal Konseling dan Pendidikan, 5(3), 109-114. 